\title{
Avrupa Birliği ve Türkiye'nin Suriyeli Mültecilerin Dayanıklılığını Geliștirme Stratejileri
}

\section{Zelal Başak Kızılkan}

Öz: Suriyeli sığınmacıların zorluklar ve şoklar karşında dayanma, direnme ve toparlanıp eski haline gelme potansiyelleri olarak tanımlanan "dayanıklıı̆ının" ulusal ve uluslararası düzeyde geliștirilmesi, Suriyeli mültecilerin toplumsal, siyasi ve kültürel entegrasyonuna önemli bir katkı sunmaktadır. Makalenin temel amacı Türkiye ve Avrupa Birliği'nin Suriyeli mültecilerin "dayanıklıık" kapasitesini güçlendirmeye yönelik politikalarının ve araçlarının neler olduğu ve söz konusu araçların etkinliklerini tespit etmektir. Makale Türkiye ve AB'nin Türkiye'deki Suriye toplumunun dayanıklılığını artırmaya ne ölçüde ve nasıl katkı sunduğunu ortaya çıkarmayı hedeflemektedir.

Anahtar Kelimeler: Suriye Krizi, Dayanıklııı Stratejileri, Türkiye-AB İlişkileri, Mülteci Krizi, Komşuluk Politikası.

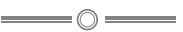

\section{The strategies of the European Union and Turkey for Building Resilience of the Syrian Refuges}

Abstract: The international actors in the field of humanitarian assistance and development- cooperation have more and more referred to the notion of resilience. Resilience is the capacity or the potential of individuals, communities or states to cope with and to recover from external and internal shocks. The EU and Turkey, hosting high numbers of Syrian refuges, has been attempting to enhance resilience potential of the Syrian refuges. Instead of focusing just on the basic needs and vulnerability, the empowerment of Syrian refuges at the individual; household and community level is important, so that they have their own resources for struggle. On this basis, the main objective of this paper is to explore to what extent and how the EU and Turkey have contributed to the resilience building of Syrian refuges in Turkey. This paper will firstly focus on Turkish legal framework for the protection of refuges, secondly resilience building strategies of Turkey and the EU and lastly the challenges and opportunities for building resilience.

Keywords: Syrian Crisis, Resilience Building, Refuge Crisis, Turkey-EU Relations, Neighbourhood Policy.

Dr. Öğr. Üyesi, Mardin Artuklu Üniversitesi, ỉktisadi ve İdari Bilimler Fakültesi, Siyaset Bilimi ve Uluslararası Ilişkiler Bölümü. 


\section{Giriș}

Suriye'deki iç savaşın 11 Mart 2011 tarihinde Ürdün sınııındaki Dera ketinde patlak vermesinden bu yana tam yedi yıl geçti. Esad rejiminin Dera'daki barışçl gösterileri zor kullanarak bastırması, çatışmaları önce bir iç savaşa, Rusya ve Amerika gibi ülkelerin müdahil olmasıyla birlikte de iç savaşı topyekûn bir savaşa dönüştürdü. Sonuçları itibariyle Suriye iç savaşı Ortadoğu'daki en büyük insani felaketlerden birini doğurdu. Birleşmiş Milletler(BM) verilerine göre, Mart 2018 itibariyle 5,6 milyondan fazla Suriyelinin Türkiye, Ürdün, Lübnan, Irak ve Mısır gibi ülkelerde mülteci statüsüne sahip olmasına, 6.1 milyon kişinin ülke içinde yerlerinden edilmesine, yaklaşık 6 milyonu çocuk olmak üzere 13 milyondan daha fazla kişinin insani yardıma gereksinim duymasına neden oldu. ${ }^{2}$ Güvenli ve onurlu bir yaşam arayışı binlerce Suriyeli sığınmacının riskli deniz yollarını kullanarak Avrupa'ya kaçmasına yol açtı. Avrupa, íkinci Dünya Savaşından bu yana en büyük göç sorunuyla karşı karşıya kaldı, ancak mülteci sorunuyla da baş edebilecek iradeyi de göstermekte zorlandı.

Mülteci krizi Türkiye ve AB ilişkilerini de ciddi bir biçimde etkiledi. Suriyeli sığınmacılar için Türkiye'nin Avrupa'ya açılan transit bir ülke olması çok sayıda mültecinin $A B$ sınırlarına dayanmasına neden oldu. $A B$ Suriyeli mültecileri Avrupa bütünleşmesini tehdit etme potansiyeline sahip "sınırdaki düşmanlar" olarak görmüş ve mülteci akını karşısında sınır politikalarını yeniden sorgulamaya başlamıştır. Türkiye ise sığınmacılara $A B$ ile ilişkilerinde kullanılabilecekleri bir "koz" ve "tehdit aracı" olarak yaklaşmıştır. Bu durum hem Türkiye'nin hem de $A B$ 'nin Suriyeli mültecilere yönelik politikalarını önemli ölçüde etkilemiştir. $A B$, Suriyeli mültecilerin Türkiye'de sürekli olarak kalmalarını ve bütünleşmelerini sağlayacak önlemleri destekleyip, Avrupa sınılarına mülteci akınını engellemeyi planlarken, Türkiye Avrupa Birliği'nden sağlanan fonlarla göçmenlerin entegrasyonundan kaynaklanacak iktisadi ve sosyal yükü azaltmaya çabalamıştır. Ayrıca, Avrupa Birliği Türkiye'nin insan hakları ve demokratikleşme sicilini ve giderek artan otoriterleşme eğilimini eleştirdiğinde, $A B$ 'yi Suriyeli mültecilere sınırları açmakla tehdit etmiştir. Toplumlar düzeyinde hem $A B$ ülkelerinde, hem de Türkiye'de Suriyeli mültecilerle bir arada yaşamaya ilişkin sorunlar ortaya çıkmıştır. Aşırı milliyetçilik, yabancı düşmanlığı ve radikalleşme gibi siyasi ve sosyolojik eğilimler giderek artmıştır.

Daha az üzerinde durulan bir konuysa Suriyeli sığınmacıların hayata tutunma çabalarıdır. Milyonlarca Suriyeli evini ve yurdunu terk edip, diline ve kültürüne yabancı olduğu bir ülkede ve çoğu kez "öteki" olarak görüldükleri bir düzlemde yaşadıkları travmaları geride bırakıp, sağlık, barınma, eğitim, temel hak ve özgürlüklerinin korunması ve statüsüzlük gibi sorunların üstesinden gelmeye çalışarak, ayağa kalkmak için uğraş vermektedir. Suriyeli sığınmacıların zorluklar

\footnotetext{
2 UN News, Syria. Haberin mevcut olduğu web sayfası https://news.un.org/en/focus/syria. Son erişim tarihi: 03.05.2018. BBC Türkçe, Grafiklerle: Suriye'de 8.yılına giren savaş, 15 Mart 2018. Web sayfası: https://www.bbc.com/turkce/haberler-dunya-43414137. Son erişim tarihi: 25.07.2018.
} 
karşında dayanma, direnme ve toparlanıp eski haline gelme potansiyelleri olarak tanımlanan "dayanıklılıklarının"3 ulusal ve uluslararası düzeyde geliştirilmesine hem Avrupa Birliği hem de Türkiye önemli bir destek vermektedir. Bu bağlamda, söz konusu makalenin temel amacı Türkiye ve Avrupa Birliği'nin Suriyeli mültecilerin "dayanıklılık” kapasitesini güçlendirmeye yönelik politikalarının ve araçlarının neler olduğu ve etkinliklerini tespit etmektir. Makale Türkiye ve AB'nin Türkiye'deki Suriye toplumunun dayanıklılığını artırmaya ne ölçüde ve nasıl katkı sunduğunu ortaya çıkarmayı hedeflemektedir.

Makale üç temel bölümden oluşmaktadır. İlk bölümde Türkiye’nin mülteci politikası ele alınacaktır. Türkiye'nin göç ve iltica politikasının hukuki ve kurumsal dayanakları analiz edilecektir. İkinci bölümde AB'nin Türkiye'deki Suriyeli sığınmacıların dayanıklılık kapasitesini artırma politikaları yerinden zorla edilmiş toplulukların dayanıklıı̆̆ını güçlendirmeye yönelik kuramsal çerçeveye referans verilerek analiz edilecektir. Bu bölümde AB-Türkiye arasında imzalanan göç anlaşmasına özel bir vurgu yapılacaktır. Son bölümde $A B$ ve Türkiye'nin Suriyeli göçmenlerin dayanıklılığını geliştirme politikasının uygulamada ne derecede etkin olup olmadığı tartışılmaya açılacaktır.

\section{Türkiye'nin Göç ve ilttica Politikası}

Türkiye mülteci tanımını 28 Temmuz 1951 yılında imzalanan ve 22 Nisan 1954 tarihinde yürürlüğe giren BM’nin “Mültecilerin Hukuki Durumuna iliş̧kin Cenevre Sözleşmesi” uyarınca yapmaktadır. Söz konusu sözleşmeye göre mülteci "Ocak 1951'den evvel cereyan eden hâdiseler neticesinde ve ırkı, dini, tabiiyeti, muayyen bir içtimaî gruba mensubiyeti veya siyasi kanaatleri yüzünden takibata uğrayacağından haklı olarak korktuğu için vatandaşı olduğu memleket dışında bulunuyorsa oraya dönemeyen veya mezkur korkuya binaen dönmek istemeyen şahıs" ${ }^{4}$ olarak tanımlanmıştır. Bir kimsenin mülteci olarak tanınması için ırkı, dini, tabiiyeti ve toplumsal gruba mensubiyetine ilişkin bir tehlikenin olması, bu gerekçelerle zulme uğrayacağına dair haklı bir korkunun olması ve ülkesinin dışında olması gerekmektedir. Sözleşme, mülteci tanımını “Ocak 1951 yılından önce ve Avrupa'da meydana gelen olaylar” ifadesiyle sınırlayarak, II. Dünya Savaşı sırasında yerinden edilen ancak mülteci statüsü olmayan kimselere hukuki bir statü getirmeyi hedeflemiştir.

1967 yılında “Mültecilerin Hukuki Statüsüne Dair 1967 Protokolü”nün benimsenmesiyle birlikte "yeni mülteci ortamlarının" ortaya çıktığı belirtilmiş ve bu nedenle zaman ve coğrafi sınırlamaya bakılmaksızın Cenevre

\footnotetext{
3 Kriz, şok ve stres gibi beklenmedik ve zorlayıcı olaylar karşında toparlanıp eski haline dönüşme güç ve kapasitesi olarak tanımlanan "resilience" kavramının, Türkçe karşıı̆̆ını bulmada önemli belirsizlikler vardır. Börekçi ve Gerçek'in (2017) vurguladığı gibi kavramın Türkçe karşılığı dayanıkııık, dirençlilik, direniş, esneklik, kendini toparlama, yılmazlık olarak kullanılmıştır (Börekçi \& Gerçek, 2017 s.45). Söz konusu çalıșmada "resilience" zorluklar "karşısında dayanma, direnme ve toparlanıp eski haline gelme" olarak kavramsallaştırılacak ve Türkçe karşılığı "dayanıklılık" olarak kullanılacaktır.

4 Birleşmiş Milletler, Madde 1.A. Mültecilerin Hukuki Durumuna Dair Sözleşme, 28 Temmuz 1951, Cenevre. Madde 1. A
} 
Sözleşmesi'ndeki mülteci tanımına giren herkesin eşit hukuki statüden yararlanabileceği ifade edilmiştir. ${ }^{5}$ Yani ek protokolle birlikte ülkelerinden ne zaman ve nereden çıkmış olduklarına bakılmaksızın, Cenevre Sözleşme ile ortaya çıkan haklar tüm mülteciler için geçerli olmuştur. Ancak, Türkiye Cenevre Sözleşmesinin mülteci tanımlamasını kabul etmesine ve Mültecilerin Hukuki Statüsüne Dair 1967 Protokolü 1 Temmuz 1968'de onaylamasına rağmen, Cenevre Sözleșmesinde belirtilen coğrafi sınırlama ilkesini uygulamaya devam etmiştir. Bu nedenle sadece Avrupa ülkelerinden siyasi gerekçelerle kaçan kişilere mülteci statüsü vermiştir. Afrika veya Orta Doğu ülkeleri gibi Avrupa coğrafyası dışındaki yerlerden Türkiye'ye kaçmak durumunda olan ve korunma talep eden kimselere mülteci statüsü verilmemiștir. Bu durumdaki kimseler "sığınmacı" olarak tanımlanmıştır.

Türkiye, 1990’lı yılların başında sınırdaşı olduğu ülkelerdeki çalkantılar nedeniyle sayıları giderek yükselen sığınma başvurularını göz önünde bulundurarak, 14.09.1994 tarihinde “Türkiye'ye İltica Eden veya Başka Bir Ülkeye ilttica Etmek Üzere Türkiye'den İkamet İzni Talep Eden Münferit Yabancılar İle Topluca Sığınma Amacıyla Sınırlarımıza Gelen Yabancılara ve Olabilecek Nüfus Hareketlerine Uygulanacak Usul ve Esaslar Hakkında Yönetmeliği"ni ${ }^{6}$ kabul etmiştir. Bu belge hem toplu hem de bireysel sığınma vakalarında sığınmacılara sağlanacak hakları ve korunma biçimlerini belirleyen ilk düzenleyici belge konumundadır (Kaya \& Eren, 2015 s.22). Ancak, Türkiye'nin mülteci ve sığınmacılara ilişkin temel hukuksal dayanağını 6458 sayılı Yabancılar ve Uluslararası Koruma Kanunu(YUKK)olușturmaktadır. ${ }^{7}$ YUKK, Türkiye'nin ulusal mevzuatını Avrupa Birliği standartları ile uyumlaştırmayı hedeflemektedir (Kibar 2013, s:109). Kanun mülteci krizine daha etkin bir biçimde yanıt verebilecek bir hukuksal dayanağı oluşturmaktadır. Esas itibariyle, “yabancıların Türkiye'ye girişleri, kalışları ve çıkışlarını” düzenlemekte ve "Türkiye'den koruma talep eden yabancılara sağlanacak korumanın kapsamına ve uygulamasına ilişkin usul ve esasları" belirlemektedir (Dulkadir 2017, s:29). Ayrıca İçişleri Bakanlığı'na bağlı Göç İdaresi Genel Müdürlüğü'nün kuruluş, görev ve sorumluluklarını da düzenler. Söz konusu kanunun benimsenmesi AB'nin reform baskısı sonucuyla oluşmuştur.

YUKK mülteci, şartlı mülteci, ikincil koruma ve geçici koruma olmak üzere dört statü öngörmüştür. Mülteci statüsü YUKK'un 61. Maddesinde düzenlenmiş, Cenevre Sözleșmesi'ne paralel olarak sadece Avrupa'dan gelen ve sığınma talep edenleri "mülteci" statüsünde değerlendirilmiştir. Avrupa dışındaki ülkelerden gelen ve mülteci vasfını taşıyan kişiler "bireysel bir koruma biçimi” olan "şartlı

\footnotetext{
5 Birleşmiş Milletler, Mültecilerin Hukuk Statüsüne ilişkin 1967 Protokolü, Madde 1.

6 Türkiyeye İltica Eden veya Başka Bir Ülkeye İltica Etmek Üzere Türkiye'den İkamet İzni Talep Eden Münferit Yabancılar ile Topluca Sığınma Amacıyla Sınırlarımıza Gelen Yabancılara ve Olabilecek Nüfus Hareketlerine Uygulanacak Usul ve Esaslar Hakkında Yönetmelik. Kabul tarihi: 14.09.1994. No: 22127.

7 Resmi Gazete, Yabancılar ve Uluslararası Koruma Kanunu, Kanun No.6458. Kabul tarihi: 04.04.2013.
} 
mülteci" hukuk rejimine tabii olmuştur. Şartlı mülteci statüsü sadece üçüncü bir ülkeye yerleşinceye kadar geçici bir koruma sağlamaktadır. ${ }^{8}$

YUKK'un 63. Maddesi ikincil koruma statüsünü düzenlemiştir. İkincil koruma statüsü "mülteci veya şartlı mülteci" kategorisinde olmayan ancak "menşei veya ikamet ülkesine gönderilmesi durumunda ölüm cezasına mahkûm olacak veya ölüm cezası infaz edilecek, işkenceye, insanlık dışı ve onur kırıcı muameleye maruz kalacak kimselerin" ikincil korumadan faydalanabileceğini belirtmiştir. ${ }^{9}$ ikincil koruma da tıpkı şartlı mülteci statüsü gibi bireysel bir koruma biçimidir. Tüm bu statülerin dışında geçici koruma statüsü de öngörülmektedir. Diğer koruma biçimlerinden farklı olarak, geçici koruma kitlesel sığınmacı akını durumunda alınacak tedbirleri ve insani yardımın sağlanmasını öngörmektedir. Bireysel ve sürekli olmayan bir statüdür. Geçici korumadan “ülkesinden ayrılmaya zorlanmış, ayrıldığı ülkeye geri dönemeyen, acil ve geçici koruma bulmak amacıyla kitlesel olarak" Türkiye sınırlarına gelenler ${ }^{10}$ faydalanabilirler (Kaya ve Eren, 2015, s: 33). Aşağıdaki bölümlerde ayrıntılı bir biçimde tartışılacağı gibi Suriyeli sığınmacılar geçici koruma statüsüne tabidirler.

\section{Avrupa Birliği'nin Dıș ilișkilerinde Dayanaklılık}

$A B$, dayanıklılığı "bir bireyin, bir hane halkının, bir topluluğun veya bir bölgenin uzun vadeli kalkınmadan ödün vermeksizin, stres ve şoklara hazırlıklı olma, başa çıkma, uyum sağlama ve şok ve krizleri en kısa zamanda atlatıp, ayağa kalkma becerisi" olarak tanımlamıştır (European Commission, 2012 s.5). Krizler ve şoklar doğal ve insan kaynaklı olabilirler (Council of European Union, 2013 S.2).

AB'nin dayanıklılık perspektifinin temel iki boyutu vardır: Bunlardan ilki toplulukların veya bireylerin doğası gereği stres ve şok ile daha iyi baş edebilme kapasitesidir. İkincisi, söz konusu varlıkların, krizin ve şokun etkisinden eski haline en kısa zamanda dönebilme becerisi veya esnekliğidir. Bu durumda $A B$ bir taraftan toplulukların gücünün artırılmasını, bir taraftan da krizin veya şokun etkisinin azaltılmasını hedefleyen politikaları aynı anda uygulamayı öngören bir dayanıklılık stratejisi benimsemiştir.

AB dış ilişkilerinde dayanıklılık artırma yaklaşımını ilk kez Afrika'daki gıda güvenliği krizinde somutlaştırmıştır. Komisyon 2012'de 30 milyondan fazla insanın açlık çektiği Afrika ülke ve toplulukların dayanıklıığını geliştirmek için uzun vadeli ve sistematik bir perspektifin geliştirilmesi gerekliliğini vurgulamıştır (European Commission, 2012). Böylece ilk defa doğal felaketler, ekonomik krizler, iklim değişikliği ve çevresel bozulma nedeniyle karşılaşılan risklerin azaltılması için hassas ülke ve toplulukların desteklenmesi AB'nin stratejilerinden biri haline gelmiştir (European Commission, 2012). Başlangıçta gıda güvenliği çerçevesinde

\footnotetext{
8 iç İşleri Bakanlığı, Göç İdaresi Genel Müdürlüğü, 6485 Sayılı Yabancılar ve Uluslararası Koruma Kanunu, Yayın No:3, Aralık 2013, Madde 62.

9 YUKK, 63. Madde

${ }^{10}$ YUKK, 91. Madde
} 
ele alınan dayanıklılık stratejisi; kalkınma, ticaret ve işbirliği, enerji (Juncos, 2017 s:13), savunma ve güvenlik (European Commission, 2014a; European Commission, 2016c) gibi alanlara genişletilmiştir.

Özellikle Arap Baharının ardından AB, Komşuluk Politikası ve dış ilișkilerine güçlü bir dayanıklılık perspektifi getirmiştir. AB Komisyonu Başkan Yardımcısı ve Güvenlik ve Dış Politika Yüksek Temsilcisi Federica Mogherini tarafından Haziran 2016'da açıklanan Küresel Güvenlik ve Dış Politika Stratejisi'nde (European Council, 2016 s.23) AB güvenliğinin ve istikrarının sadece içsel faktörlere bağlı olmadığı, aynı zamanda dış dünya ve komşu bölgelerdeki istikrar ile yakından alakalı olduğu anlayışı belirtilmiştir. Küresel Strateji'nin dört öncelikli alanından bir tanesi de devletlerin ve toplumların krizlere dayanma kapasitelerinin geliştirilmesidir. Küresel strateji doğuda Orta Asya'ya ve güneyde Orta Afrika'ya uzanan toplulukların ve devletlerin dayanaklığının artırılmasını amaçlamıştır.

\subsection{AB'nin Dayanıklılık Artırma Stratejisi}

AB'nin yerlerinden edilmiş kişiler ve mülteciler gibi hassas konumdaki hane halklarının ve topluluklarının dayanıklılığını artırması komşuluk ve dış politika alanlarında öncelikli olarak hedeflemiştir (Council of European Union, 2013 s.3). Avrupa Birliği'nin yerinden edilmiş kimselere yönelik dayanıklılık stratejisi 26 Nisan 2014 tarihinde benimsemiş olduğu Avrupa Komisyonu, Avrupa Parlamentosu, Ekonomik ve Sosyal Komite ve Bölgeler Komitesine sunmuş olduğu "Onurlu Yaşamlar: Yardım Bağımlılığından Kendine Yeterliliğe: Zorla Yerinden Edilme ve Kalkınma (Foreign Affairs Council, 2016 )" adlı bildirisi ve aynı bildiriye istinaden Komisyon'un hazırlamış olduğu Komisyon Çalışma Belgesinde ortaya koyulmuştur (European Commission, 2016b). Bu düzenlemelerle $A B$ yerinden edilmiş kimselerin insani yardıma olan bağımlılıklarını ortadan kaldırarak, kendilerine yetebilen, misafir olduğu toplumlara katkı sağlayan ve böylece onurlu bir yaşam sürdürebilmelerine olanak tanıyan, bağlama özel, kapsayıcı bir politika çerçevesi çizmeye çalışmıştır. $A B$, insan haklarının korunması, çatışmaların önlenmesi, insani yardım gibi farklı konulardaki yaklaşımları bir araya getirerek, ortaya çıkan bağları işlevsel olarak güçlendiren, kapsayıcı bir perspektif oluşturmuştur (European Commission, 2016a s:7).

AB'nin yeni yaklaşımının temel olarak üç boyutu vardır (European Commission, 2016b s.6). Birinci olarak, insani yardım ve kalkınma stratejilerinin yanı sıra, yerinden olma gibi ciddi bir travmayla yüzleşen sığınmacıların krizle baş edebilme güçlerini artırma stratejileri boyutudur. Bununla yerinden edilmiş kimselerin kısa vadeli sorunlarını çözen insani yardım perspektifiyle sığınmacıların tekrar ayağa kalkmalarını sağlayacak, dayanıklılık geliștirici orta vadedeli programları uzun vadeli kalkınma stratejileri ile birleştirmek hedeflenmiştir.

İkinci olarak, AB yerinden edilmiş kimselerin dayanıklıı̆̆ını artırmak için yerel ve ulusal düzeyde işbirliğinin ve diyaloğun artırılmasını öngörmüştür. Bu yaklaşım öz itibariyle uluslararası hukukta ve insan hakları hukukunda 
sığınmacıların korunmasına ilișkin sorumluluğun devletlere verilmesinden kaynaklanmaktadır. Hükümetler esasen sağladığı yasal ve politik çerçevelerle yerinden edilmiş kimselerin ihtiyaçlarının nasıl ele alınabileceğine ilişkin temel parametreleri belirlerler. Bu nedenle $A B$ uzun vadeli strateji ve kalkınma planlarını ev sahibi ülkelerle politika diyaloğunu geliştirerek oluşturmaya çabalamıştır. Somut olarak AB'nin ev sahibi devletlerle diyaloğundan bekledikleri adımlar a) tüm yerinden edilmiş nüfusun kayıt altına alınması ve böylece yeni bir devletsiz topluluğun oluşmasının engellenmesi, b) yerinden edilmiş kimselere korunmanın sağlanması, d) ev sahibi ülkenin sosyal ve ekonomik yaşamına aşamalı olarak entegre edilmesi ve yerel makamlarla şehir planlaması, bölgesel iktisadi kalkınma ve hizmetlerin sunulması gibi alanlarda kapasitenin geliştirilmesi için daha fazla merkezi olmayan işbirliğinin geliştirilmesidir (European Commission, 2016b s:10-11). Üçüncü boyut ise, Avrupa Birliği'nin dayanıklılık inşası stratejisinde sektörel müdahale alanlarını belirtmektedir. Söz konusu alanlar eğitim sektörü, emek piyasasına erişim ve temel hizmetlerin sağlanması gibi müdahale alanlarını içermektedir (European Commission, 2016b s:10-11).

\section{Eğitim sektörü müdahale alanı}

AB'nin müdahale alanlarından ilki eğitimdir. Avrupa Birliği'ne göre yerinden edilmiş kimselere sağlanan eğitim olanaklarının eksikliği sosyal ve ekonomik refahın azalmasına, insan kaynaklarında nesiller arası bir düşüşe, umutsuzluğa, marjinalleşmeye, cinsel sömürüye, suç, şiddet ve radikalleşme riskine neden olabilmektedir (European Commission, 2016b s:12-13). Bu nedenle, yerinden edilmiş kimselere eğitimin sağlanması AB'nin dayanıklılık planının öncelikli konuları arasında yer almaktadır. AB'ye göre dayanıklılık programının en temel hedefi hem yerlerinden edilmiş nüfusa hem de yerel nüfusa anaokulu, ilkokul, ortaokul ve yüksek öğrenim düzeylerinde “eşit ve kaliteli” eğitim sağlamaktır (European Commission, 2016b). Bu anlamda kalkınma işbirliği çerçevesinde ev sahibi topluluklara bütçe yardımı yapılması ve alt yapı oluşturma desteği verilmesi öngörülmüştür. Ayrıca yerinden edilmiş çocuklara dil eğitimi sağlanması da desteklenmektedir. (European Commission, 2016b).

\section{Emek piyasasına erişim müdahale alanı}

AB'nin dayanıklılık planının diğer bir ayağı ise yerinden edilmiș kimselerin emek piyasasına erişimlerinin sağlanması ve böylece mültecilerin insani yardıma bağımlılıklarının azaltılmasıdır (European Commission, 2016b s.14). AB, emek piyasasına erişimin mültecilere ekonomik bağımsızlık sağlamanın yanı sıra, onların ev sahibi topluluklarla uyum içerisinde olmalarına ve ev sahibi ülkenin dillerini öğrenmelerine yardımcı olacağına ve bu durumun ev sahibi ülkenin üzerindeki mali ve siyasi baskıyı azaltacağına inanmaktadır. $A B$, sığınmacıların iş piyasasına erişimin olmaması durumunda kayıt dışı ekonomide çocuk işçiliği, zorla çalıştırma, sömürücü iş biçimleri gibi olumsuz durumların ortaya çıkabileceğini vurgulamıştır. Bu nedenle AB'nin yerinden edilmiş kimselerin 
dayanıklılıklarını iş piyasasına erişimlerini sağlayacak hukuksal çerçevenin oluşturulması vasıtasıyla gerçekleştirilebileceğine inanılmaktadır.

\section{Temel hizmetlerin sağlanması müdahale alanı}

Barınma, sağlık, beslenme, koruma gibi sığınmacıların ihtiyaçları sadece insani yardım ile karşılanmaz. Sığınmacıların temel kamu hizmetlerinden dışlanması onların yardımlara bağımlı olmasına ve böylece sürdürülebilir kalkınma süreçlerinin engellenmesine neden olabilir. $A B$ zorla yerinden edilenlerin kamu hizmetlerine eşit ve adil bir şekilde erişmelerinin sağlanması gerektiğine inanmaktadır. Bu anlamda Avrupa Birliği ev sahibi ülkelere a) yerinden edilmiş kimselere hizmet sunma ve sosyal koruma programları geliştirme konusunda yardımcı olmayı, b) ev sahibi devletlere ve sivil toplum örgütlerine sığınmacıların temel gereksinimlerinin karşılanması konusunda bütçe sağlamayı, c) mültecilere ve zorla yerlerinden edilmiş insanlara güvenlik ve adalet hizmetlerinin genişletilmesi konusunda teşvik ve destek sağlamayı taahhüt etmiştir (European Commission, 2016b s.15-16).

Yukarıda belirtilen müdahale alanları, sığınmacıların ev sahibi ülkelerde dayanıkııı̆ıını artırması bakımından oldukça önemlidir. İnsani bir kriz karşısında yumuşak bir güç olan AB'nin benimseyeceği normatif bir çerçeveye atıfta bulunmaktadır. Ancak uygulamada AB'nin dayanıklılık geliştirme stratejisi, AB sınırlarına dayanmış olan sığınmacıları Türkiye gibi geçiş ülkelerinde kabul edilebilir bir "mutluluk" ve "refah” düzeyini sağlayarak, AB'nin sınırları dışında tutabilme çabasıdır. Bir başka ifadeyle, dayanıklılık stratejisi AB'nin normatif soslarla tatlandırılmış pragmatist tutumundan başka bir şey değildir. Bu durumun en somut yansımasını ise AB-Türkiye arasında 16 Aralık 2013 tarihinde imzalanan Geri Kabul Antlaşması'nda bulmak mümkündür.

\subsection{Türkiye-AB ilișkilerinde Göç ve Geri Kabul Antlaşması}

Geri Kabul Antlaşması ${ }^{11}$ AB'ye üye ülkelerin birine yasa dışı yollarla giren, Türk vatandaşlarının, vatansızların, Türkiye'nin ikili geri kabul antlaşmasının olduğu "üçüncü ülke vatandaşlarının Türkiye’ye geri kabulünü, söz konusu antlaşmada belirtilen şartlar ve kurallar çerçevesinde," öngören bir antlaşmadır (Güder 2016, s:133). Antlaşma 1 Ekim 2014'te yürürlüğe girmekle birlikte, Türkiye'nin ikili geri kabul antlaşmasının olmadığı üçüncü ülke vatandaşlarının geri kabulünü 1 Ekim 2017 tarihinden itibaren uygulanmasını öngörmüştür (European Commission, 2016b)

Geri Kabul Anlaşması karşılığında Türkiye, Türk vatandaşlarının vizesiz AB'ye girişini öngören Vize Serbestisi Diyaloğunun başlatılması (European Commission, 2016d s.2), üyelik müzakerelerinde ilerleme ve nakdi yardım sözleri almıştır. Ancak bu sözler karşılıksız değildir. Türkiye $A B$ ile ortaklaşa hazırladığı

\footnotetext{
1 Official Journal of the European Union, Agreement betweeen the European Union and the Republic of Turkey on the Re-admission of Persons Residing without Authorisation, L 134/3.
} 
Vize Muafiyeti Yol Haritasında belirtilen “a)Seyahat Belgelerinin Güvenliği, b) Göç Yönetimi, c) Kamu Düzeni ve Güvenliği ve d)Temel Haklar” alanlarında 72 kriteri gerçekleştirmek zorundadır. ${ }^{12}$ Türkiye'nin yol haritasına paralel olarak atacağı adımlar AB Komisyon'un raporları tarafından incelenmeye alınacak (European Commission, 2014b, 2016e; Commission, 2016f), Komisyon yapılan reformlardan tatmin olursa, Avrupa Parlamentosu ve $A B$ Konseyi'ne Türkiye'ye uygulanan vizelerin kaldırılabilmesini önerebilecektir. Parlamento'daki oylamada salt çoğunluk, Konsey'deki oylamada nitelikli çoğunlukla vize serbestisi kararı alınabilecektir. Ayrıca, AB Türkiye'ye “kapasite artırımı ve geçici koruma altındakilerin ihtiyaçlarının karşılanmasında kullanılmak üzere 3 milyar avroluk ek kaynağı" da içeren toplamda 6 milyar avroluk bir mali desteği ve teknik yardımı taahhüt edecektir. ${ }^{13}$ Kısaca, Türkiye politik ilişkilerin yoğunlaştırılması, mali teşvikler ve vize muafiyeti karşılığında istenmeyen ziyaretçileri Avrupa sınırından uzak tutacaktır.

Ancak, geri Kabul Antlaşması geçici koruma altında olan kimselerin haklarıyla ilgili ciddi riskler taşımaktadır. Öncelikle antlaşma Türkiye ve Avrupa Birliği geri kabul antlaşması ile vize muafiyeti arasında bir ilişki kurmuş ve Suriyeli mültecileri bir pazarlık konusu yapmıştır. Kamuoyuna geri kabul antlaşması vize muafiyetinin bir ön koşulu olarak sunulmuştur. Oysa AB ile Türkiye arasında vize muafiyeti tartışması 2000'li yılların başına kadar gitmektedir (Ekinci, 2016 s:18). Vize muafiyeti ve geri kabul antlaşması arasında illiyet bağı yoktur. Turist vizesi üzerinden yaşamları tehdit altında olan insanların geri gönderilmesine ilişkin bir pazarlık sürdürmek normatif bir pozisyon değildir. Ayrıca, Türkiye üzerinden Avrupa'ya gitmeye çabalayan kimseler genel olarak insan hakları ihlallerinin ve çatışmaların yoğun olarak yaşandığı ülkelerden kaçmaya çalışan kimselerdir. Aşağıda ayrıntılı bir şekilde tartışıldığı gibi Türkiye 1951 Cenevre Mülteci Sözleşmesi ve 1967 New York Protokolüne getirdiği coğrafi çekince nedeniyle Avrupa dışından iltica talebinde bulunanları mülteci olarak kabul etmemektedir. Bu nedenle güvenli iltica ülkesi değildir. Türkiye'de etkili koruma usullerinin olmaması yerinden edilmiş kimselerin dönemin siyasi iradesine bağlı olarak kaynak ülkeye rahatlıkla gönderilmesine neden olabilecektir. Bu olasılık ileriki süreçte Türkiye'nin Avrupa'ya en çok mülteci gönderen kaynak ve transit ülkelerle geri kabul antlaşmaları imzalamasıyla artacaktır. Gerçekte, Türkiye 10 Eylül 2001 tarihinde Suriye ile imzalamış olduğu Geri Kabul Antlaşmasını esas alarak 2002-2013 yılları arasında 2675 Suriyeli mülteciyi Esad rejimine teslim etmiş ${ }^{14}$ ve bu insanların hayatlarının riske atılmasına neden olmuştur. Son olarak, AB'nin katı güvenlik mekanizmalarını güçlendirmeye yönelik göç politikasıysa

\footnotetext{
${ }^{12}$ Mehmet Uğur Ekinci, Türkiye-AB Geri Kabul Anlaşması ve Vize Diyaloğu, SETA Rapor, 2016, s: 34.

13 ibid.

${ }^{14}$ Senar Ataman, Geri Kabul Antlaşması, AB ve Türkiye, 22 Nisan 2014. Web sitesi: http://multeci.net/?p=379. Son erişim tarihi. 15.07.2018.
} 
insan ticareti ve kaçakçılığı yapan suç şebekelerini güçlendirmekte ve bu durum sığınmacıların yaşamlarını da tehdit etmektedir. ${ }^{15}$

$A B$, Geri Kabul ve Vize Muafiyeti antlaşmasıyla giderek artan mülteci akınını durdurmayı ve böylece mültecilerin bütünleșme projesine getireceği siyasi ve iktisadi maliyeti dışsallaştırmayı hedeflemiştir. Söz konusu antlaşmalar bir nevi AB'nin sınır kontrol mekanizmalarını güçlendirmenin yollarından bir tanesidir. $A B$ düzensiz göçü sınırları dışında kontrol ve denetim altına almayı ve böylece sorumluluktan kurtulmayı hedeflemiştir. Bu nedenle Komisyon'un Vize Muafiyeti Yol Haritasında istenilen reformların önemli bir bölümü sınır güvenliği ve yönetimi ve vize rejiminin $A B$ standartlarına uygun hale getirilmesi gibi teknik konuları içermektedir. AB'nin Türkiye'den sığınmacıların geçimlerini sağlama, kamu hizmeti ve soysal haklardan yararlanma ve Türkiye toplumu ile uyumun sağlanması gibi mültecilerin dayanıklııı kapasitesini artırmaya yönelik reform talebi oldukça sınırlıdır. Sınır yönetimi ve belge güvenliğine ilişkin reformlarla $A B$ 'nin doğuya doğru genişleyen sınırlarının güvenliği ve kontrolünün sağlanmasına ilișkin güçlü bir vurgu söz konusudur. Fonların kimlere ve hangi nedenlerle dağıtılacağına ilişkin açık bir ifade yoktur.

Toplamak gerekirse, AB için yerinden edilmiş kimselerin dayanıklılıklarının geliştirilmesi insani ve normatif olmaktan ziyade araçsal bir yaklaşımı ifade etmektedir. Yerinden edilmiş kimselerin sürdürülebilir ve asgari bir refah düzeyine sahip olması ve böylece Türkiye gibi $A B$ 'ye sınırdaş ülkelerde yaşamlarını sürdürme olanaklarının artırılması, AB'nin Suriyeli sığınmacıları çeperinde tutmanın yollarından biridir. Geri Kabul Antlaşması ve Vize Muafiyeti Yol Haritası gibi belgelerin lafzı ve ruhunda Suriyeli göçmenlerin krizler karşısında ayağa kalkma kapasitesi olarak tanımlanan dayanıklılık geliştirmeye yönelik zayıf vurgusunun altında böylesi bir perspektif yatmaktadır. Bir başka ifadeyle, Geri Kabul Antlaşması ve Vize Muafiyeti antlaşmasıyla Türkiye'ye sağlanan fonlar Suriyeli mültecileri güçlendirmekten ziyade, Türkiye hükümetinin “jandarma” rolü karşılığında verilen bir bedel olarak da değerlendirilebilir. Yerinden edilmiş kimselere yönelik böylesi güvenlik eksenli bir yaklaşımın altında sığınma hakkının Birlik sınırları dışında veya çeperinde tutulması anlayışı yatmaktadır. Böylece $A B$ yerinden edilmiş kimseleri koruma sorumluluğunu Türkiye'ye devretmekte ve sığınmacıların haklarının üstü örtülü bir biçimde ihlaline neden olmaktadır.

\section{Türkiye'nin Sığınmacıların Dayanıklılığını Artırma Stratejileri}

Suriye'den Türkiye'ye ilk mülteci akını Suriye'deki iç savaştan kaçan sayıları yüzlerle ifade edilebilecek mültecinin 29 Nisan 2011 tarihinde Türkiye’ye sığınma talebinde bulunmasıyla başlamıştır. Türkiye hükümeti, Suriyeli sığınmacıların iltica talepleri karşısında "açık kapı” politikasını uygulamaya koymuştur. İlk olarak da bir sınır kenti olan Hatay’da kamplar kurmaya başlamıştır. Suriye’deki krizin ilk

\footnotetext{
${ }^{15}$ Cahide Sarı, Geri Kabul Anlaşması: Bir Taşeronlaştırma Zinciri, Ayrıntı Dergi. Web sitesi: http://ayrintidergi.com.tr/geri-kabul-anlasmasi-bir-taseronlastirma-zinciri/. Son erişim tarihi: 10.08.2018.
} 
aylarında çatışmaların yakın zamanda sona ereceği ve sığınma talep eden Suriyelilerin kısa vadede ülkelerine geri dönecekleri göz önünde bulundurulmuştur. Bu nedenle, Türkiye Suriyeli sığınmacılara yönelik kalıcı tedbirler almaktan ziyade, kamplarda ikamet eden Suriyelilere acil insani yardım sağlamıştır. Suriyeli sığınmacılara yönelik kısa vadeli çözümlerin yetersizliği, Türkiye'nin dayanıklılık inşasına ilişkin uzun vadeli stratejileri geç de olsa benimsemesine neden olmuştur.

Türkiye'nin Suriyeli mültecilerin dayanaklılıklarını artırmaya yönelik stratejilerinin iki temel boyutu vardır. Bunlardan ilki Suriyelilere sağlanacak hak ve yükümlülükleri belirleyecek olan hukuksal zemin, ikincisiyse, yasal mevzuatının Suriyeli mültecilerin dayanıklılık kapasitelerini artırmaya yönelik uygulanmasıdır.

\subsection{Suriyelilerin Dayanıklılığının Artırılması Hukuksal Çerçevesi}

Türkiye Suriye iç savaşı nedeniyle ülkesini terk etmek zorunda olan ve günümüzde sayıları 3 milyonu aşan sığınmacıyı mülteci statüsünde değerlendirmemiştir. Savaşın başlangıcında Suriyelileri misafir olarak görmüștür (Kaya \& Eren, 2015 s: 48). İçişleri Bakanlığınca hazırlanan, “Türkiye’ye Toplu Sığınma Amacıyla Gelen Suriye Arap Cumhuriyeti Vatandaşlarının ve Suriye Arap Cumhuriyetinde ikamet Eden Vatansız Kişilerin Kabulüne ve Barındırılmasına iliş̧kin Yönerge" ile sadece barınak, yiyecek, hijyen gibi günlük temel ihtiyaçları sağlamaya yönelik tedbirler alınmıştır. Suriyelilerin sanıldığından daha uzun ikamet edeceği anlaşılınca, Türkiye kalıcı tedbirler almaya başlamış, hukuki statülerinin ve akabinde sağlanacak korumanın biçimlerine ilişkin bir tartışma doğmuştur.

Suriyeli sığınmacıların dayanıklılığını artırmaya yönelik en önemli adım, uzun vadeli korumanın hukuksal bir zemininin oluşturulmasıdır. Hukuki olarak Suriyeliler Avrupa dışından geldikleri için mülteci olarak değerlendirilememiştir. $\mathrm{Bu}$ nedenle, Suriyeli sığınmacıların hukuksal durumunu belirlemek amacıyla, ağırlıklı olarak AB'nin baskıları sonucunda, yukarıda belirtilen 6458 sayılı Yabancılar ve Uluslararası Koruma Kanunu benimsenmiștir. ${ }^{16}$ Bu kanun etkili bir iltica ve göç yönetimini hedefleyerek, Suriyelilere sağlanan hakları uluslararası standartlara uygun hale getirmiştir. Kanun göç alanına ilişkin politika ve stratejileri uygulamak, göç alanında çalışma yürüten "kurum ve kuruluşlar arasında koordinasyonu sağlamak, yabancıların Türkiye'ye giriş ve Türkiye'de kalışları, Türkiye'den çıkışları ve sınır dışı edilmeleri, uluslararası koruma, geçici koruma ve insan ticareti mağdurlarının korunmasıyla ilgili iş ve işlemleri yürütmek üzere Göç İdaresi Genel Müdürlüğü’nün” kurulmasını öngörmüştür. ${ }^{17}$ Bu kanunla

\footnotetext{
${ }^{16}$ iç İşleri Bakanlığı Göç İdaresi, Yabancılar ve Uluslararası Koruma Kanunu, Yayın No: 3, Aralık 2013. http://www.goc.gov.tr/files/files/goc_kanun.pdf. Son erişim tarihi: 10.08.2018.

${ }^{17}$ İç İşleri Bakanlığı, Göç İdaresi Genē Müdürlüğü, 03.01.2007. Web sayfası: http://www.goc.gov.tr/icerik6/gocidaresinden-sorumlu-vali-yardimcilari-toplantisi-yapildi_359_5766_427_icerik. Son Erişim Tarihi: 10.08.2018.
} 
birlikte Göç Idaresi Genel Müdürlüğü 81 ilde, 148 ilçede ve yurtdışında teşkilatlanmıştır. ${ }^{18}$

Söz konusu kanun mülteci, şartlı mülteci, ikincil koruma ve geçici koruma gibi farklı koruma biçimlerini tanımlamıştır. Suriyeliler bir kitlesel akın sonucu Türkiye'de bulunduklarından bireysel koruma biçimi olan "şartlı mülteci" ve "ikincil koruma" statüsünde değerlendirilmemiștir. "Çok sayıda, aniden ve kitlesel olarak" Türkiye'ye girdikleri için geçici koruma hukuksal statüsüne tabii kılınmışlardır (Kaya \& Eren, 2015 s: 48). Yukarıda ayrıntılı bir biçimde tartışıldığı gibi geçici koruma "öngörülemeyen ve ivedi nitelikteki bir durum sebebiyle baş gösteren acil akınlar sonucunda göç etmek zorunda kalan kişilerin korunmasını sağlamak üzere geliştirilmiş" bir statüyü ifade etmektedir (Kaya \& Eren, 2015 s: 33).

6458 sayılı Yabancılar ve Uluslararası Koruma Kanununun 91. Maddesi geçici korumaya ilişkin temel noktaları belirledikten sonra, uygulamaya yönelik ayrıntıları bir yönetmelikle düzenlemeyi öngörmüştür. Bu hükme istinaden Geçici Koruma Yönetmeliği 22.10.2014 tarihinde yürürlüğe girmiştir. ${ }^{19}$ Geçici Koruma Yönetmeliğinin geçiş hükümlerini düzenleyen geçici Madde 1'e göre Suriye'de olan olaylar yüzünden Türkiye'ye kitlesel veya bireysel olarak gelen Suriye vatandaşlarının geçici koruma altına alınmasını öngörülmüştür. Yönetmelik "uluslararası koruma talebi bireysel olarak değerlendirmeye alınamayanlara sağlanabilecek geçici koruma işlemlerinin usul ve esasları ile bu kişilerin Türkiye'ye kabulü, Türkiye'de kalışı, hak ve yükümlülükleri, Türkiye'den çıkışlarında yapılacak işlemleri, kitlesel hareketlere karşı alınacak tedbirleri ve ulusal ve uluslararası kuruluşlar arasındaki işbirliğiyle ilgili hususları" düzenlemiştir. $^{20}$

\subsection{Geçici Koruma ve Suriyelilerin Dayanıklılığını Artırmaya Katkısı}

Hukuksal alanda yapılan düzenlemelerin dışında, Türkiye Suriye mülteci krizinin ve ülkede halihazırda ikamet eden mülteci topluluklarının değişen gerçeklerine bir yanıt olarak, farklı alanlardaki politikaları yeniden düzenlemiştir. Mülteci krizine ilişkin devlet merkezli yaklaşım yerine uluslararası örgütleri ve sivil toplum örgütlerini politika yapım ve uygulama süreçlerine katan iyi yönetişim perspektifini benimsemiştir (içcduygu, 2015 s:9). Aynı şekilde, mülteci krizinden insani yardım ekseninden çıkarak kısa vadeli acil müdahaleye dayalı politikalar yerine, Suriyeli mültecilerin Türkiye ile toplumsal uyumunu mümkün kılacak ve onların dayanıklılık kapasitelerini artıracak uzun vadeli politikaları benimsemiştir. Başlangıçta Suriyeli mültecilerin kabul ve yardımlarının dağıtılmasına ilişkin asıl sorumluluk Türk Kızılayı ve AFAD gibi örgütlerin inisiyatifine bırakılırken, zaman içerisinde Göç İdaresi Genel Müdürlüğü kurulmuştur. Kurumsallaşma mülteci

\footnotetext{
18 ibid.

${ }^{19}$ Geçici Koruma Yönetmeliği, Bakanlar Kurulu Tarihi: 13.10.2014. No: 2014/6883. Yayınlandığı Düsturun Tertibi: 5. Cilt: 55 .

${ }^{20}$ Ibid.
} 
politikasında önemli bir değişimin ve uzun vadeli planlama ihtiyacının önemli bir işaretidir. $^{21}$

Geçici koruma mevzuatı Suriyeli vatandaşların dayanıklılık kapasitesini geliştirmeye ve toplumsal uyumu artırmaya yönelik önlemleri düzenlemiştir. Suriyeli mültecilere "sağlık, eğitim, iş piyasasına erişim, sosyal yardım ve hizmetler ile tercümanlık ve benzeri hizmetler" sağlanması öngörülmüştür. ${ }^{22}$ Geçici Koruma Yönetmeliğinin 27. Maddesi, Suriyeli sığınmacılara sağlanacak sağlık hizmetlerini ayrıntılı bir biçimde düzenlemiştir. ${ }^{23}$ Söz konusu maddeye göre Suriyelilere geçici barınma merkezlerinde ve merkezlerin dışında Sağlık Bakanlığı'nın kontrolünde sağlık hizmetlerinin sağlanması güvence altına alınmıştır. Sağlık hizmetlerini yürütmek üzere geçici barınma merkezlerinin içinde sürekli faaliyet gösterecek sağlık merkezleri kurulabilmektedir. Ayrıca, Suriyeliler hastaneler ve sağlık ocaklarında tedavi görebilirler. Sunulan sağlık hizmetinin bedeli AFAD tarafından ödenir. Geçici barınma merkezlerinin bulunduğu koşulların sağlık açısından uygun hala getirilmesi sağlanır.

Yönetmeliğin 28.Maddesinde Suriyelilere sağlanacak eğitim hizmetleri hüküm altına alınmıştır. Geçici korumaya tabii olan Suriyeliler okul öncesi eğitim ve öğretim, ilköğretim ve orta öğretim ve her yaş grubuna yönelik olarak dil eğitimi ve meslek edinme, beceri ve hobi kurslarının isteğe bağlı olarak düzenlenmesini mümkün kılmıştır. ${ }^{24}$ Suriyelilere yönelik eğitim faaliyetlerinin düzenlenmesi için Milli Eğitim Bakanlığı Temel Eğitim Genel Müdürlüğü "Yabancılara Yönelik Eğitim ve Öğretim Hizmetlerini" benimsemiştir. Yönetmeliğin 29. Maddesi geçici koruma statüsünde olanların iş piyasasına erişim haklarını güvence altına almıştır. Bakanlar kurulunca belirlenecek sektörlerde, iş kollarında, coğrafi alanlarda, çalışma iznini Çalışma ve Sosyal Güvenlik Bakanlığından alabilecekleri belirtilmiştir. ${ }^{25}$

Yabancılar ve Uluslararası Koruma Kanunu ve Geçici Koruma Yönetmeliği Suriyeli mültecilerin acil insani ihtiyaçlarına cevap verebilecek ve aynı zamanda sağlık ve eğitim hizmetlerine erişimleri mümkün kılacak güçlü bir iltica çerçevesi oluşturmuştur.

\subsection{Türkiye'nin Bölgesel Mülteci ve Dayanıklılık Planı}

Göç İdaresi Genel Müdürlüğü sığınmacıların dayanıklılık ve toplumsal uyumunu sağlamaya yönelik 2017-2021 Stratejik Planı hazırlamıştır. ${ }^{26}$ Stratejik

\footnotetext{
${ }^{21}$ ibid.

${ }^{22}$ Geçici Koruma Mevzuatı, Madde 26. Ayrıca bakınız: Türkiye Cumhuriyeti Aile ve Sosyal Politikalar Bakanlığı, Türkiye'de Geçici Koruma Statüsündeki Suriye Vatandaşlarına Yönelik, Sosyal Uyum ve Psiko-Sosyal Destek Çalışmaları, Suriyeliler Koordinasyon ve Planlama ve Çalıştayı, s: 59. Ankara, 2016.

${ }^{23}$ Geçici Koruma Mevzuatı, Madde 27.

${ }^{24}$ Geçici Koruma Mevzuatı, Madde 28

${ }^{25}$ Türkiye Cumhuriyeti Aile ve Sosyal Politikalar Bakanlığı, Türkiye'de Geçici Koruma Statüsündeki Suriye Vatandaşlarına Yönelik, Sosyal Uyum ve Psiko-Sosyal Destek Çalışmaları, Suriyeliler Koordinasyon ve Planlama ve Çalıştayı, s: 59. Ankara, 2016.

${ }^{26}$ TC. İçişleri Bakanlığı, Göç İdaresi Genel Müdürlüğü, Stratejik Plan,
} 
Plan düzenli göç, düzensiz göç, uluslararası koruma, insan ticaretiyle mücadele ve mağdurların korunması, uyum ve iletişim, kurumsal kapasitesinin geliştirilmesi gibi konularda hedefler belirlemiștir. Stratejik plan kısa vadeli amaçların yanı sıra, Suriyelilerin Türkiye toplumu ile olan karşılıklı uyumunu geliștirmeye yönelik uzun vadeli hedefler de saptamıştır. Suriyelilerin 1) eğitim, 2) sağlık, 3)temel ihtiyaçlar, 4) emek piyasasına erişim 5) sosyal destek ve uyum gibi beş farklı alanda dayanıklılık kapasitelerinin geliştirilmesi hedeflenmiştir.

Eğitim alanında dayanıkılı̆̆ın geliştirilmesi Milli Eğitim Bakanlığı'nın koordinasyonunda gerçekleştirilmektedir. Buradaki temel amaç Suriyeli mültecilerin örgün, örgün olmayan ve yaygın eğitim programlarına erişimlerini sağlamak ve sağlanan eğitim hizmetlerinin kalitesini artırmaktır. ${ }^{27}$ Suriyeli mültecilere kamplar dışında kurulan Geçici Eğitim Merkezlerinde(GEM), Milli Eğitim Bakanlığı'na bağlı devlet okullarında ve geçici barınma merkezlerinde eğitim verilmektedir. Türkçe dil ve meslek edindirme kursları gibi olanakların sağlanması hedeflenmektedir. Türk hükümeti ayrıca Suriyeli sığınmacılardan üniversiteye kayıtlarında harç almamaktadır. Ancak eğitim sektörü müdahale alanında önemli sıkıntılar hala mevcuttur. Söz konusu sıkıntıların başında örgün eğitime entegrasyonlarını sağlayacak yeterli düzeyde Türkçe dil eğitiminin verilmemesi, Türkçe öğretiminde materyal sıkıntısının çekilmesi, okullaşmanın artmasıyla Suriyeli öğretmenlere duyulan ihtiyacın artması, Suriyeli nüfusun fazla olduğu yerlerde okullarda boş kontenjanın bulunmaması, okullaşamayan çocukların marjinalleşmesi ve DAiş gibi örgütlere katılma eğilimi gibi sorunlar eğitim müdahale alanının temel sıkıntıları arasında yer almaktadır (Tanrıkulu, 2017 $\mathrm{s}: 135-140)$.

Sağlık sektörü alanı da Türkiye hükümetinin Suriyeli mültecilerin dayanıklılığını artırma müdahale alanlarındandır. Suriyelilere sağlık hizmetlerinin sunulması ve koordinasyonundan Sağlık Bakanlığı ve Başbakanlık Afet ve Acil Durum Yönetim Başkanlığı sorumludur. Suriyeliler Türkiye'de hem önleyici ve koruyucu hizmet hem de tıbbi kaynaklara ulaşım bakımından sağlık hizmetlerinden faydalanabilmektedir (Yavuz, 2015s: 271). Tıbbı kaynaklara erişim bağlamında Suriye'de barınma merkezlerinde ikamet eden mültecilere Sağlık Bakanlığı tarafından sağlık hizmeti sunulmaktadır. Kamplarda kalan Suriyeli mültecilere sağlanan sağlık hizmeti ücretsizdir. Kamplar dışında ikamet eden Suriyelilerin söz konusu sağlık hizmetlerine ulaşmada savaşın ilk yıllarında sıkıntılar yaşanmıştır. Geçici kabul merkezlerinin ve kampların dışında yaşayan Suriyelilerin, kampların bulunduğu 10 ildeki sağlık kurumlarından faydalanmaları sağlanmıştır. Suriyeli mültecilerin Türkiye'nin diğer bölgelerinde yaşamaya başlamasıyla birlikte AFAD tarafından yayınlanan bir yönergeyle sağlık hizmetinden Türkiye'nin her ilinde faydalanma olanağı sunulmuştur. Koruyucu sağlık hizmetleri sağlığı bozabilecek tehditleri önlemeye yönelik tedbirlerdir. Bu

\footnotetext{
27 ibid.
} 
anlamda gıda güvenliği, barınma koşullarının sağlanması, yeterli besin gibi insani yardım müdahale alanıyla da yakından ilintilidir.

Hem temel ihtiyaçlar müdahale alanında hem de koruyucu sağlık hizmetleri bağlamında, 22.11.2017 tarihi itibariyle Türkiye hükümeti 21 geçici barınma merkezi inşa etmiş ve 235.239 Suriyeli sığınmacıya barınma olanağı sağlamıştır. ${ }^{28}$ Toplu barınma merkezlerinde ikamet eden Suriyeli mültecilerin su, hijyen ve alt yapı olanakları geliştirilmiștir. Gıda sektörü müdahale alanı AFAD ve Dünya Gıda Programı (WFP) öncülüğünde ve Uluslararası Göç Örgütü (IOM), Birleşmiş Milletler Gıda ve Tarım Örgütü (FAO) ortaklığında yürütülmektedir. Gıda güvenliği sektörünün birinci hedefi en hassas konumdaki Suriyelinin gıdaya istikrarlı bir şekilde erişimin sağlanmasıdır. Bunun dışında da sürdürülebilir üretimin desteklenmesi hedeflenmiștir. İnsani yardım müdahale alanındaki temel sorun kamp dışında ikamet eden Suriyeli mültecilere yardım sağlanmasıdır. Bu bağlamda, Kızılay-WFP Gıda Kartı projesiyle Geçici Barınma Merkezlerinde aylık kişi başı 50TL gıda yardımı sağlanmış ve söz konusu projeden 11.422.395 kişi faydalanmıştır. ${ }^{29}$ Benzer bir biçimde Geçici Barınma Merkezleri dışında ikamet eden 98.829 sığınmacıya aylık kişi başı 50 TL gıda yardımı sağlanmıştır. Ayrıca Kızılay-UNICEF Kışlık Yardım projesi bağlamında 6702 aileye 580 TL nakit aktarılmıştır ve Uluslararası Göç Örgütü ile birlikte yürütülen Kışlık Yardım projesi kapsamında 2992 aileye yakacak desteği sağlanmıştır. ${ }^{30}$

Suriyeli mültecilerin istihdama erişimlerinin sağlanması gelir elde etmeleri bakımından oldukça önemlidir. Emek gücüne katılım Suriyeli mültecilerin dayanıklılık kapasitesini artıracak ve kendilerine yetmelerini sağlayacak en temel unsurlardan bir tanesidir. Suriye krizinin ilk yıllarında Suriyeli mültecilerin çalışma haklarının olmaması emeklerinin sömürüldüğü ve iş güvence ve güvenliğinin olmadığı mevsimlik tarım işçiliği gibi işlerde çalışmak zorunda kalmalarına neden olmuştur. Bu durum hala sürmekle birlikte, "6458 sayılı Yabancılar ve Uluslararası Koruma Kanunu” geçici koruma altındaki kimselere çalışma hakkının tanınmasıyla kısmen çözülmüştür. Kanunla ayrıca Suriyeli mültecilerin emek gücüne katılımlarının pratikte sağlanması hedeflenmiştir. Türkiye hükümeti bu alana Suriyeli nüfusa istihdam için gerekli becerilerin kazandırılması için eğitim programları sağlayarak ve böylece serbest meslek becerilerinin geliştirilmesini destekleyerek müdahale etmiştir.

Suriyeli mültecilerin toplumsal uyumu "geliştirme, yönlendirme ve eğitim hizmetleri" artırmak hedefiyle Toplum Merkezleri oluşturulmuştur. ${ }^{31}$ Toplum merkezleri "çocuk programı, yetişkin programı, ihtiyaca yönelik seminerler, saha

\footnotetext{
${ }^{28}$ TC Başbakanlık Afet ve Acil Durum Yönetimi Başkanlığı, 22.11.2017. Web sitesi:https://www.afad.gov.tr/upload/Node/2374/files/22_11_2017_Suriye_GBM_Bilgi_Notu.pdf. Son erişim tarihi: 18 Temmuz 2017.

${ }^{29}$ Türkiye Cumhuriyeti Aile ve Sosyal Politikalar Bakanlığı, Türkiye'de Geçici Koruma Statüsündeki Suriye Vatandaşlarına Yönelik, Sosyal Uyum ve Psiko-Sosyal Destek Çalışmaları, Suriyeliler Koordinasyon ve Planlama ve Çalıștayı, s: 59. Ankara, 2016.

30 ibid.

31 ibid.
} 
çalışmaları, yönlendirme, ev sahibi halkla kaynaştırma, kültürel faaliyetler ve psiko-sosyal faaliyetler" gibi alanlarda hizmet vermektedir. ${ }^{32}$ Çocuk ve yetişkin programlarında dil kursları, toplumsal uyumu artıracak sosyal ve kültürel faaliyetler, mesleki eğitim gibi hizmetler sağlanmaktadır. Yönlendirme faaliyetlerinde Suriyelilerin sağlık ve eğitim hizmetlerine yönlendirilmeleri, ihtiyaç sahibi kimselerin tespit edilmesi, merkezi yönetim tarafından sağlanan hizmetlere ulaşma şansı olmayan Suriyelilere yönelik bilgilendirme etkinlikleri düzenlenmektedir. 33

\section{AB ve Türkiye'nin Dayanıklılık İnșası Stratejilerinin Etkinliği}

Avrupa Birliği Suriyeli mültecilere insani yardımı Avrupa Topluluğu İnsani Yardım Bürosu (ECHO) bünyesinde oluşturulan Türkiye Mülteci Tesisi ile sağlamaktadır. Söz konusu tesisin amacı Türkiye'deki geçici koruma altındaki sığınmacılara $A B$ yardımlarının hızlı ve etkili bir biçimde ulaştırılabilmesi için bir koordinasyon mekanizması sağlamaktır. Türkiye Mülteci Tesisinin odak noktası insani yardım, eğitim, göç yönetimi, sağlık, belediye altyapısı ve sosyal-ekonomik destektir. 4.06.2018 tarihi itibariyle insani yardım ve insani yardım dışındaki destek faaliyetlerinin uygulanması 6 Milyar Avro taahhüt edilerek sözleşmeye bağlanmıştır. ${ }^{34}$ Bunun 1.94 Milyar Avro'luk bölümünün ödemeleri gerçekleşmiştir. ${ }^{35}$ Ayrıca, Suriyeli mültecilerin dayanıklılık kapasitesini artırma amacıyla $A B$ Güven Fonunu benimsenmiștir. $A B$ Güven Fonu vasıtasıyla Aralık 2014'ten bu yana Suriye'nin komşu olduğu ülkelere, yani Mısır, Irak, Ürdün, Lübnan'a ve Türkiye'de yaşayan 1,5 milyona yakın Suriyeliye insani-olmayan yardım sağlanması hedeflenmiștir. ${ }^{36}$ Fonun amacı Suriyeli mültecilerin uzun vadeli eğitim, ekonomik ve sosyal ihtiyaçlarını ele almaktır. Fon öncelikli olarak çocuklar ve gençler için eğitim olanaklarının artırılması ve geçim kaynakları ve toplumsal uyum gibi hem mültecilere hem de ev sahibi topluluklara fayda sağlayacak alanlara müdahale etmeyi öngörmekteydi.

$A B$ verilerine göre en büyük insani yardım kalemi Dünya Gıda Programının talebi doğrultusunda Suriyeli mültecilerin günlük ihtiyaçlarının karşılanmasına yönelik Acil Durum Sosyal Güvenlik Ağı (ESSN) tarafından sağlanan 278 Milyon 400 bin Avroluk yardımdır. Avrupa Birliği’nin ikinci büyük yardım kalemiyse UNICEF'e sağlanan 34 milyon Avroluk hibedir. Bu fon İnsani Yardım Acil Durumlarda Eğitim öncelik alanında yer alan mülteci çocukların kayıt oranının ve derse devamlılı̆̆ın artırılması için sağlanan şartlı nakit transferidir. ${ }^{37}$ Ayrıca, Katılım Öncesi Yardım Aracı(IPA) ve İçişleri Göç İdaresi kapsamında Türkiye'ye dönen mültecilerin ihtiyaçlarının karşılanması için 12 milyon Avro ve IPA'nın Milli

\footnotetext{
32 ibid.

33 ibid

${ }^{34}$ European Commission, The EU Facility for Refuges in Turkey. Web Page: https://ec.europa.eu/neighbourhoodenlargement/sites/near/files/frit_factsheet.pdf. Son erişim tarihi. 11.08.2018. 35 lbid.

${ }^{36}$ Avrupa Birliği Türkiye Delegasyonu, AB Suriye Güven Fonu: Suriyeli Mültecilere ve Ev Sahibi Topluluklara Destek için Sağlananan Yeni Yardım Paketi 1 Milyar Avro Sınırını aştı.

37 ibid.
} 
Eğitim Bakanlığı ile yaptığı antlaşma ile 90 milyon Avro, Sağlık Bakanlığıyla yaptığı antlaşma ile de 120 milyon Avro yardım yapılmıștır. ${ }^{38}$ Toplamak gerekirse, Avrupa Birliği fonlarının yüzde 46'sı insani yardıma, yüzde 15 'i mültecilerin sağlık hizmetine ulaşımının sağlanmasına, yüzde 28 'i eğitime, yüzde 8 'i sosyoekonomik desteğe ve yüzde 3'ü göç yönetimine sağlanmaktadır. ${ }^{39}$

Türkiye hükümeti ve Avrupa Birliği geçici koruma altındaki sığınmacıların dayanıklılığını artırmaya yönelik müdahalelerde bulunmuştur. Söz konusu müdahaleler onların karşı karşıya kaldıkları kısa vadeli gıda, barınma, sağlık, eğitim gibi temel sorunlarını çözmeye ilişkin etkili ve önemli adımlardır. Ancak söz konusu adımlara rağmen yukarıda bahsi geçen müdahale alanlarında önemli sıkıntılar bulunmaktadır. Öncelikli olarak çocuklar ve kadınlar gibi hassas konumda olan gruplar hala yapısal sorunlardan mustariptir. Suriyeli mülteci çocukların okullaşma oranı oldukça düşüktür. Yüzde elliden fazlası okula kayıt yaptırmamaktadır. Çocukların birçoğu çocuk işçiliği, çocuk yaşta yapılan evlilikler, radikalleşme, doğum belgesi alamama, aile içi şiddete maruz kalma gibi sorunlarla başa çıkmaya çabalamaktadır. Bir diğer sorunsa Suriyeli sığınmacılar arasında cinsel ve toplumsal cinsiyete dayalı şiddet vakalarında önemli bir oranda artışın olmasıdır. Mağdurlar sadece kadınlar ve kız çocukları değildir. Erkekler ve LBGT bireyleri toplumsal şiddete maruz kalmaktadır. Diğer bir sorunsa dil sorunudur. Eğitim ve sağlık hizmetlerinden etkin bir biçimde yararlanılmasını engelleyen sıkıntı dildir. Ayrıca mültecilerin önemli bir kısmı psikolojik yardıma ihtiyaç duymaktadırlar. Suriyeli mülteciler Türkiye toplumunun yeni ötekileri olmuştur. Türkiye'de ekonominin durağanlaşmasıyla birlikte Suriyeli mülteciler giderek daha fazla fiziksel saldırıya varacak düzeyde yabancı düşmanlığına maruz kalmıştır.

\section{Sonuç}

Pratikte yaşanan sorunların yanı sıra Suriyeli mültecilerin dayanıklılıklarının inşası AB'nin dış ilişkilerine getirmiş olduğu “ilkeli faydacılığın” bir tezahürüdür. AB'nin yüksek miktarda fonu Türkiye aktarması özünde Suriyelilerin temel insani haklarından biri olan sığınma hakkının bizatihi AB tarafından ihlalini perdelemeye yönelik yaklaşımdır. Insani yardım ve dayanıklılık inşası bağlamında Türkiye'de yaşayan mültecileri fonlayarak $A B$, mülteci akınını durdurmayı hedeflemektedir. Fonların etkin ve adrese ulaşan bir şekilde verilip verilmediğine bakılmaksızın ve Türkiye'nin demokrasi ve insan hakları alanındaki reform isteksizliğine rağmen, Türkiye AB'nin mültecilere karşı jandarma rolünü üstlendiği sürece, $A B$ Türkiye hükümetini fonlamaya ve reform karşılığında mali yardım temeli üzerine kurulu siyasi şartlılığın temel prensibini göz ardı etmeye devam edecektir.

\footnotetext{
${ }^{38}$ T24, İnan Ketenciler, AB Suriyeli Mülteciler için Türkiye'ye şu ana kadar 676 milyon 600 bin avro yardım yaptık, 28 Kasım 2016. Son erişim: 24 Temmuz 2014.http://t24.com.tr/haber/ab-suriyeli-multeciler-icin-turkiyeye-su-anakadar-676-milyon-60o-bin-avro-yardim-yaptik,373522

${ }^{39}$ Factsheet, Education, Health and Socio Economic Support Under the EU Facility,
} 
Türkiye'nin de Suriyeli mültecilere yaklaşımı AB'den çok farklı değildir. Tıpkı AB gibi güvenlik-istikrar ve normatif değerler arasında ikileme düştüğünde, Türkiye güvenliği tercih etmektedir. Geçtiğimiz yıllarda Türkiye Suriye sınırında $9000 \mathrm{~km}$ uzunluğunda ve 3 buçuk metre derinliğinde duvarın inşasını tamamlayarak dolaylı bir biçimde $A B$ 'nin sınır güvenliğine katkıda bulunmuştur. ${ }^{40}$ Mültecilerle ilişkilerindeyse mültecileri insani ihtiyaçları olan ve ileriki süreçte Türkiye toplumunun bir parçası olacak kimselerden ziyade $A B$ ile ilişkilerinde önemli bir koz olarak değerlendirmiştir. $A B$ ile ilişkilerin siyasi gerekçelerle gerilmesi durumunda AB'yi Suriyeli mültecilere sınırları açmakla tehdit etmiştir.

Suriyeli mültecilere yönelik güvenlik merkezli uygulamalar ve özellikle Geri Kabul Antlaşması Suriyeli mültecilerin sığınma hakkını AB'nin dışında tutmasına neden olmaktadır. Bu durum bir taraftan AB'ye yönelik göç akışının illegalleşmesi bakımından önemli bir işlev görürken, diğer taraftan insan kaçakçılığı ve kaçak çalıştırma gibi rant alanlarının ortaya çıkmasına neden olmaktadır. Güvenlik merkezli uygulamalar mültecilerin en temel hakkı olan yaşam hakkının ihlaline ve emeklerinin sömürülmesine neden olmaktadır. Bu durum mültecilerin ev sahibi ülkeyle toplumsal bütünleşmesini ciddi bir biçimde etkilemektedir. Yasal olmayan yollarla $A B$ sınırlarını geçmeye çalışan mültecileri engelleme ve geri gönderme üzerine kurulu bir yaklaşım yeni fiziksel ve fiziksel olmayan duvarların inşasına neden olmakta ve söz konusu duvarlardan geçmeye çalışanları caydırmak üzerine kurulu bir güvenlik piyasası oluşturmaktadır. Kısaca, AB sınırlarında merkezileşen ve Türkiye gibi AB'nin çeperinde olan ülkelere yayılan göç yönetimi bir taraftan göçmenleri illegalleştirmekte, AB'nin insani yardım fonlarıla önemli bir tezatlık oluşturmaktadır. Ancak bundan daha önemlisi Suriyeli mültecilerin yaşama tutunmalarını sağlayacak daha iyi çalışma ve hak arama mücadelelerinde önemli bir bariyer oluşturmaktadır.

\section{Kaynakça}

Börekçi, D. Y., \& Gerçek, M. (2017). Resilience Kavramının Sosyal Bilimlerde Türkçe Kullanımları Bağlamında Değerlendirilmesi. Pamukkale University Journal of Social Sciences Institute.

Commission, European. (2012). Communication from the Commission to the European Parliament and the Council: The EU Approach to Resilience: Learning From Food Security. Brussels, European Commission.

Commission, European. (2014a). Communication from the Commission to the European Parliament and the Council on the short term resilience of the European gas system Preparedness for a possible disruption of supplies from the East during the fall and winter of 2014/2015, Brussels 16.10.2014, COM (2014) 654. . Brussels

\footnotetext{
${ }^{40}$ Sputnik, Suriye Sınırına Örülen Mödüler Beton Duvarda 774 Kilometre Tamam, https://tr.sputniknews.com/columnists/201711221031106429-suriye-sinirina-orulen-moduler-duvar/ Son Erişim Tarihi: 11.08.2018.
} 
Commission, European. (2014b). Report from the Commission to the European Parliament and the Council: First Report on Progress by Turkey in Fullfulling the Requirments of its Visa Liberalization Roadmap.

Commission, European. (2016a). Commission Staff Working Document. Accompanying the document Communication from the Commission to the European Parliament, the Council, the European Economic and Social Committee and the Committee of the Regions Lives in Dignity: from Aiddependence to Self-reliance Forced Displacement and Development.

Commission, European. (2016b). Communication from the Commission to the European Parliament, the Council, the European Economic and Social Committee and the Committee of the Regions: Lives in Dignity: From Aid Dependence to Self Relience: Forced Displacement and Development; $\operatorname{COM}(2016)$ Brussels.

Commission, European. (2016c). Joint Communication to the European Parliament and the Council: Joint Framework on Countering Hybrid Threats: A European Response, Brussels 06.04.2016. Brussels.

Commission, European. (2016d). [Proposal for a Regulation of the European Parliament and of the Council amending Regulation (EC) No: 539/2001 listing the third countries whose nationals must be in possession of visas when crossing the external borders and those whose nationals are exempt from that requirement ].

Commission, European. (2016e). Report from the Commission to the European Parliament and the Council: Second Report on Progress by Turkey in Fullfulling the Requirments of its Visa Liberalization Roadmap.

Commission, European. (2016f). Report from the Commission to the European Parliament and the Council: Third Report on Progress by Turkey in Fullfulling the Requirments of its Visa Liberalization Roadmap. Retrieved from

Council of Foreign. Affairs. (2016). Shared Vision, Common Action: A Stronger Europe: A Global Strategy for the European Union's Foreign and Security Policy.

Ekinci, M. U. (2016). Türkiye-AB Geri Kabul Anlaşması ve Vize Diyaloğu. Retrieved from İstanbul:

Güder, M. (2016) Türkiye'deki Dış Göç Olgusuna Sosyoekonomik Bir Yaklaşım ve Avrupa Birliği ile Geri Kabul Antlaşması'nın Olası Etkileri, Vol 24 (30), 129-137.

İçduygu, A. (2015). Syrian Refugess in Turkey: The Long Road Ahead.

Juncos, A. E. (2017). Resilience as the new EU foreign policy paradigm: a pragmatist turn? European Security, 26(1), 1-18. doi:10.1080/09662839.2016.1247809

Kaya, İ., \& Eren, Y. E. (2015). Türkiye'deki Suriyelilerin Hukuki Durumu: Arada Kalanların Hakları ve Yükümlülükler. SETA.

Tanrıkulu, F. (2017). Türkiye'de Yaşayan Suriyeli Çocukların Eğitim Sorunu ve Çözüm Önerileri. Düşünce Dergisi, 22(86), 127-144. 
Council of European Union. (2013). Council conclusions on EU Approach to Resilience, 3241st Foreign Affairs Council Meeting Brussels, 28 May 2013. Bruseels: Council of the Europaan Union.

Yavuz, Ö. (2015). Türkiye'deki Suriyeli Mültecilere Yapılan Sağlık Yardımlarının Yasal ve Etik Temelleri. Mustafa Kemal University Journal of Social Sciences Institute, 12(30). 